\title{
UK space strategy sets sights on Mars
}

[LONDON] Britain's science minister, Lord David Sainsbury, last week announced a shift in the government's space science policy, to give more money to basic research at the expense of large Earth observation programmes.

The decision paves the way for a UK-led Mars lander project, designed to search for evidence of life on the planet.

In presenting the new strategy at the Science Museum in London, Sainsbury announced a redistribution of $\mathfrak{E} 19.5$ million (US\$31.3 million) of the $\mathfrak{E} 180$ million UK budget for space expenditure. About half of this will be used for the European Space Agency's (ESA) Artes programme, a government-industry partnership for advanced telecommunications technologies.

The rest of the money will support basic space research and the development of basic technology, which many scientists complain has been neglected.

Britain's space scientists welcomed the government's agreement to contribute

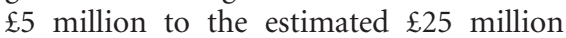
development cost of a Mars lander spacecraft, Beagle 2. The ESA has selected Beagle 2 as part of the payload of its 2003 Mars Express mission, provided that the research team can find sufficient financial support.

The Particle Physics and Astronomy Research Council (PPARC) has agreed to provide $£ 2.8$ million for the instruments for Beagle. The research team, led by Colin Pillinger, director of the Planetary Sciences Research Institute at the Open University in Milton Keynes, has also raised $\mathfrak{1} 12$ million from private sponsorship.

Beagle 2 will carry out in-situ analyses of the Martian atmosphere and geology. Unlike the US space agency NASA's Pathfinder, Beagle will have devices to retrieve material from beneath the planet's surface, where organisms could most likely survive.

It will also be capable of measuring the isotopic composition of excavated rocks, rather than just their chemistry. This is essential for understanding the nature of the processes that created the material.

The project's supporters argue that, even if no evidence of life is discovered, the mission could provide a valuable scientific service in settling the controversial question of whether life ever existed on Mars.

"If biological processes have left traces in Martian material, than Beagle is bound to find evidence," says Paul Merdin, director of science at the British National Space Centre.

Not all planetary scientists share this view. Some call the goal of the mission a "long shot" that would rely on luck. To answer conclusively questions about life on Mars would require a major drilling rig capable of excavating material from 30 to 300

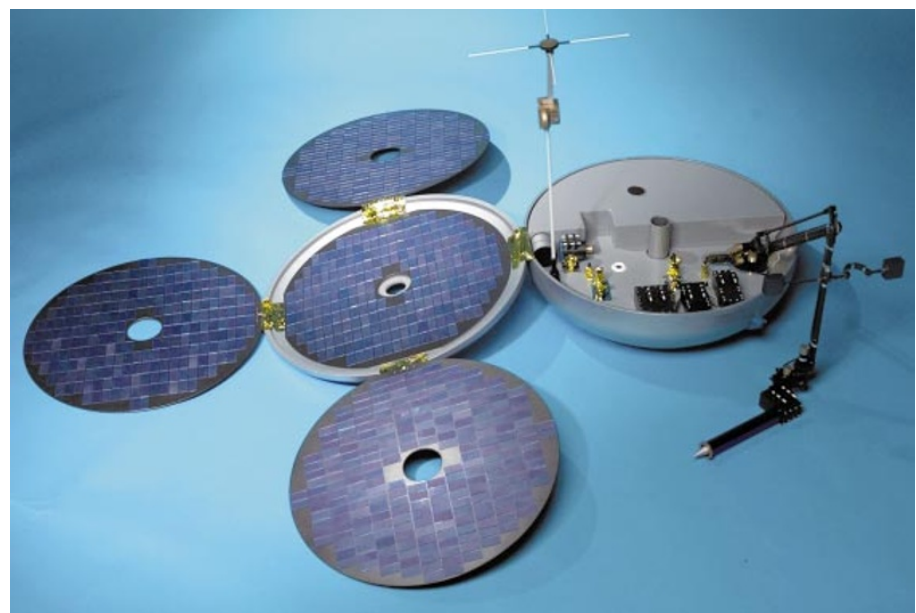

Beagle bound for Mars: the lander will excavate the planet's surface in search of evidence that life could have existed on the 'red planet'.

metres depth, they argue, rather than a robot capable only of "scraping the surface".

But both the ESA and its industrial partner, Matra Marconi Space, have confirmed the potential value of the lander following a review of the technical and scientific aspects in April. "Beagle 2 would offer unprecedented scientific opportunities," says Roger Bonnet, ESA space science director.

Pillinger's team is still short of several million pounds. This means a race against time. Beagle's financing must be secure by next January if it is to be approved as part of the Mars Express mission.

Alan Wells, director of the space research centre at the University of Leicester, which is involved in the project, predicts that Sainsbury's announcement will "serve as a catalyst for bringing in other sources of funding". Pillinger is reported to have "very good prospects" of obtaining additional funds.

The new space strategy also backs Britain's contribution to the ESA's infrared cornerstone mission First and to the microwave background cosmological mis- sion Planck, scheduled to launch together in

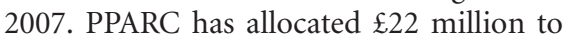
fund instruments for the two missions.

Sainsbury highlighted Britain's major involvement in ESA's Living Planet programme for environmental sciences, a planned series of small and cheap Earth observation missions. Britain will lead the first mission, Cryosat, which will monitor the impact of global warming on the polar ice caps.

Underlining a trend towards smaller and more focused missions, the UK contribution to large-scale ESA Earth observation projects has been cut by almost 25 per cent, to

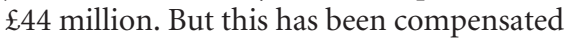
for by an increase in national programmes.

UK scientists have generally welcomed the plans. Wells agrees that the strategy is "a move in the right direction". But he criticizes the fact that the overall public space budget is only being redirected rather than expanded. "Private investment in space technology exceeds public expenditure by a factor of three," he says. "But no returns to basic research come back from industry."

QuirinSchiermeier

\section{Legal threat in bid to ban xenotransplants}

[WASHINGTON] A US advocacy group that opposes xenotransplantation threatened last week to sue the Department of Health and Human Services (DHHS) for failing to respond to a legal petition demanding a ban on the practice because of its potential health risks.

The New York-based Campaign for Responsible Transplantation (CRT) filed a petition in December asking the DHHS to ban animal-to-human transplants of cells, tissues and organs.

The legal deadline for the department's response was 10 June. If the DHHS does not respond by 17 August, says CRT, the group will sue for breach of the Administrative Procedures Act. This law allows courts to compel government agencies to take action when this has been "unreasonably delayed".

Lorrie McHugh, a DHHS spokeswoman, says, "We want to be as responsive as possible to the campaign". She says that the DHHS is preparing an interagency response to the group's "very complicated legal document". The respondents include the Food and Drug Administration and the National Institutes of Health.

CRT says that xenotransplantation poses unacceptable risks because of the danger of the transfer of deadly animal viruses to humans. In April, the Food and Drug Administration announced a de facto ban on xenotransplants from non-human primates, but left the way open for the development of transplants from pigs (see Nature 398, 549; 1999). 